\title{
EFFECT OF ROOTSTOCK AND INTERSTOCK ON GROWTH, YIELD AND FRUIY QUALITY OF SOME ORANGE VARIETIES B. FRUIT QUALITY
}

\author{
Somaia A. El-Sayed \\ Citrus Research Department, Hort. Res. Instit. ARC. Giza, Egypt.
}

Received: Feb. 22 , 2017

Accepted: Apr. 8, 2017

\begin{abstract}
This experiment was designed as long term study, started in 2008 till 2014 with the idea of using sour orange as interstock on volkamer lemon rootstock (SO/VL) for budding four orange varieties, namely, Olinda valencia ,Spring navel, Parent navel, and Fukumoto navel oranges. The purpose was to avoid some disadvantages of volkamer lemon on physical and chemical fruit quality with the hope of maintaining tree growth and its productivity with good properties acceptable for local and foreign market. The obtained results showed that, Fruit of Olinda valencia, Spring navel, Parent navel and Fukumoto navel oranges budded on the interstock were similar to those produced on sour orange in their physical fruit characters in terms of length, diameter, shape, volume, juice volume, rind thickness and segments number. Moreover, chemical fruit properties of orange scions on the interstock were also similar to those on sour orange rootstock in its higher TSS, lower acidity and higher TSS/acid ratio than those on volkamer lemon rootstock. Therefore, it is recommended to use sour orange as interstock when volkamer lemon is the given rootstock in orchard soil. Using sour orange as interstock on volkamer lemon proved to be useful in improving most fruit quality properties of the four orange varieties budded on it in this study.
\end{abstract}

Key words: Rootstock, Interstock, Budwood, Volkamer lemon, Sour orange Fukumoto navel, Parent navel, Olinda valencia, Spring navel, Fruit quality.

\section{INTRODUCTION}

Citrus rootstocks play an important role in growth and productivity of citrus in different area in the world. The effect of fruit quality has been studied on many citrus producing areas. Volkamer lemon as a rootstock have excellent effect on scions in terms of tree growth and yield, because it gave high yield and for its resistance of some Virus diseases, but it is considered poor in its fruit properties, so it was necessary to find a way to avoid these disadvantages.

In this respect, Fallahi et al 1989 and Dawood 2002 conducted that, yield of grapefruit and Washington navel orange were higher from trees on volkamer lemon and rangpur lime than those on swingle citrumelo, cleopatra mandarin and sour orange. Also, Gregoriou 2002 reported that Volkamer lemon has been reported to significantly increase yield of clementine mandarin compared with sour orange. In this respect, Al-Jaleel and Zekri 2003 revealed that, parent Washington navel on volkamer lemon, macrophylla and Rough lemon were the most productive as compared with trees on sour orange and cleopatra mandarin. This result was also concluded by Zayan et al 2004 who reported that yield as number of fruits/tree and weight ( $\mathrm{kg} / \mathrm{tree})$ of Washington navel orange was higher on volkamer lemon and rangpur lime than those on troyer citrange, sour orange and cleopatra mandarin. Also, scions on volkamer lemon produced larger and heavier fruits with thicker peel thickness, but juice quality like TSS, acid and TSS/acid ratio are undesired than that on sour orange. In this respect, Former-Giner et al 2003 showed that, fruits from Navelina orange trees on volkamer lemon showed the largest, heaviest and thickest rind as compared with cleopatra mandarin and other rootstocks. Also, Al-Jaleel and Zekri 2003 revealed that, 


\section{El-Sayed}

Parent Washington navel trees on volkamer lemon, macrophylla and rangpur lime gave the highest values of fruit size and peel thickness, whereas trees on sour orange gave the highest values of total soluble solids. Similar results were obtained by Perez-Zamora 2004 who states that volkamer lemon and macrophylla presented the lowest quality of SSC and SSC /acidity. Moreover, Zayan et al 2004 concluded that, volkamer lemon and rangpur lime as rootstock for Washington navel orange produced higher yield with good physical fruit characters in terms of length, diameter, volume and weight, whereas produced fruit with lower SSC. Therefore, it was obvious that volkamer lemon rootstock resulted in vigorous, very productive trees; however internal fruit quality of scions varieties especially Washington navel orange could be very poor.

The purpose of this long term study is to avoid or get rid of disadvantages of volkamer lemon on physical and chemical fruit properties, hopping to maintain tree growth and its productivity.

\section{MATERIALS AND METHODS}

This experiment is designed as long term study, started in 2008 with the idea of using double budding for volkamer lemon (VL) rootstock by using sour orange (SO) as interstock (SO/VL) for budding four orange varieties. In 2008 budwood for sour orange (SO) (Citrus aurantium) were budded on one year volkamer lemon (VL) (Citrus Volkameriana) seedlings as interstock .Six months later, (VL), (SO) and (SO/VL) rootstocks were prepared at the same age and budded in 2009 with four orange varieties, namely Olinda valencia, spring navel, parent navel, and Fukumoto navel orange varieties. The experiments included twelve treatments were arranged in a randomized complete block design, each treatment replicated 3 times and 3 plots for a total 9 tree per rootstock.

Thus, 108 trees $(12 \times 9)$ were planted in 2010 in a private orchard at El- Bustan region, El- Beheira Governorate, Egypt planted at $5 \times 5$ meter apart. The soil is sandy and the mechanical and chemical analysis were done as shown in Table (1). All agricultural practices were done as usual in the orchard.

In 2013 and 2014 seasons, samples and field data were recorded on the trees of the following treatments:

1- Olinda valencia orange on sour orange (SO).

2- Olinda valencia orange on volkamer lemon (VL).

3- Olinda valencia orange on interstock (SO/VL).

4- Spring navel orange on sour orange (SO).

5- Spring navel orange on volkamer lemon (VL).

6- Spring navel orange on interstock (SO/VL).

7- Parent navel orange on sour orange (SO).

8- Parent navel orange on volkamer lemon (VL).

9- Parent navel orange on interstock (SO/VL).

10- Fukumoto navel orange on sour orange (SO).

11- Fukumoto navel orange on volkamer lemon (VL).

12- Fukumoto navel orange on interstock (SO/VL).

Table (1). Mechanical and chemical analysis of experimental soil.

\begin{tabular}{|c|c|c|c|c|c|c|c|c|c|c|c|}
\hline \multicolumn{3}{|c|}{ Mechanical } & \multicolumn{2}{c|}{ Chemical } & \multicolumn{4}{c|}{ Cations (meq/l) } & \multicolumn{3}{c|}{ Anions (meq/l) } \\
\hline $\begin{array}{c}\text { Sand } \\
\%\end{array}$ & $\begin{array}{c}\text { Silt } \\
\%\end{array}$ & $\begin{array}{c}\text { Clay } \\
\%\end{array}$ & $\mathrm{pH}$ & $\begin{array}{c}\mathrm{Ec} \\
\mathrm{dS} / \mathrm{m}^{-1}\end{array}$ & $\mathrm{Na}^{+}$ & $\mathrm{Ca}^{++}$ & $\mathrm{Mg}^{++}$ & $\mathrm{CO}_{3}^{-}$ & $\mathrm{HCO}_{3}^{-}$ & $\mathrm{Cl}^{-}$ & $\mathrm{SO}^{--}$ \\
\hline 77.85 & 6.50 & 15.65 & 8.82 & 0.64 & 2.53 & 1.45 & 0.60 & - & 2.23 & 2.10 & 0.25 \\
\hline
\end{tabular}


Fruit quality in 2013 and 2014 seasons was recorded as follows :

To determine fruit quality, 10 fruits were taken at random from each tree at harvest time of both seasons, then fruit length and diameter $(\mathrm{cm})$, were measured and fruit shape was calculated, fruit weight $(\mathrm{gm})$, fruit volume $\left(\mathrm{cm}^{3}\right)$, rind thickness $(\mathrm{mm})$, segment number/fruit, juice \% / fruit were determined. Also, total soluble solids was determined by hand refractometer, total acidity as citric acid was determined according to (A.O.A.C., 1990), then TSS/acid ratio was estimated. Ascorbic acid as $\mathrm{mg} / 100 \mathrm{ml}$ juice was determined by using 2, 6 dichlorophenol indophenol according to Jacobs (1951).

\section{Statistical analysis:}

Statistical analysis was done as analysis of variance according to Snedecor and Cochran (1990), and the least significant differences (L.S.D. at 5\% level) was used to compare the mean values.

\section{RESULTS AND DISCUSSION}

\section{Fruit quality:}

\subsection{Physical fruit quality:}

Data in Table (2) show the effect of rootstock type, scions and their combined on fruit length, fruit diameter and fruit shape in both seasons. The results in Table (2) reveal that, scions on three stocks had similar fruit length and fruit diameter without significant differences among them, except fruit length parameter on sour orange and fruit diameter seemed to be variable on interstock in the first season only. Also, fruit shape values was similar among three stocks and the differences were found on trees budded on volkamer lemon rootstock in both seasons. Generally, the three stocks gave similar fruit length, diameter and shape without significant differences among them in most cases.

Table (2). Effect of rootstock and interstock on fruit length, fruit diameter and fruit shape of some orange varieties in 2013 and 2014 seasons.

\begin{tabular}{|c|c|c|c|c|c|c|c|c|c|c|c|c|}
\hline \multirow{3}{*}{ Treatments } & \multicolumn{12}{|c|}{ Rootstocks and interstock } \\
\hline & \multicolumn{4}{|c|}{ Fruit length $(\mathrm{cm})$} & \multicolumn{4}{|c|}{ Fruit diameter $(\mathrm{cm})$} & \multicolumn{4}{|c|}{ Fruit shape } \\
\hline & VL & SO & $\mathrm{SO} / \mathrm{VL}$ & Mean & VL & SO & $\mathrm{SO} / \mathrm{VL}$ & mean & $\mathrm{VL}$ & SO & SO/VL & Mean \\
\hline \multicolumn{13}{|c|}{2013} \\
\hline Olinda valencia & 7.26 & 7.37 & 8.05 & 7.56 & 7.46 & 7.22 & 7.59 & 7.43 & 0.97 & 1.02 & 1.06 & 1.01 \\
\hline Spring navel & 8.04 & 7.81 & 7.76 & 7.82 & 8.01 & 8.01 & 7.87 & 7.96 & 1.00 & 0.98 & 0.99 & 0.99 \\
\hline Parent navel & 8.75 & 5.90 & 7.93 & 7.53 & 8.56 & 8.15 & 7.45 & 8.05 & 1.02 & 0.73 & 1.06 & 0.94 \\
\hline Fukumoto navel & 7.15 & 7.83 & 7.91 & 7.63 & 7.53 & 8.11 & 7.56 & 7.73 & 0.95 & 0.97 & 1.05 & 0.99 \\
\hline Mean & 7.80 & 7.23 & 7.91 & & 7.89 & 7.87 & 7.62 & & 0.99 & 0.93 & 1.04 & \\
\hline L.S.D. at $5 \%$ & \multicolumn{4}{|c|}{$V=0.21$} & \multicolumn{4}{|c|}{$V=0.20$} & \multicolumn{4}{|c|}{$V=0.04 \quad R=0.03 \quad V x R=0.10$} \\
\hline \multicolumn{13}{|c|}{2014} \\
\hline Olinda valencia & 7.20 & 7.37 & 7.98 & 7.52 & 7.33 & 7.18 & 7.67 & 7.39 & 0.98 & 1.03 & 1.04 & 1.02 \\
\hline Spring navel & 8.15 & 7.97 & 8.07 & 8.06 & 7.98 & 7.90 & 7.87 & 7.92 & 1.02 & 1.01 & 1.03 & 1.02 \\
\hline Parent navel & 9.35 & 9.30 & 7.97 & 8.87 & 8.65 & 8.37 & 7.45 & 8.16 & 1.08 & 1.11 & 1.07 & 1.09 \\
\hline Fukumoto navel & 7.67 & 8.72 & 7.99 & 8.13 & 7.51 & 7.90 & 7.53 & 7.65 & 1.02 & 1.10 & 1.06 & 1.06 \\
\hline Mean & 8.09 & 8.34 & 8.00 & & 7.87 & 7.84 & 7.63 & & 1.03 & 1.06 & 1.05 & \\
\hline L.S.D. at $5 \%$ & \multicolumn{4}{|c|}{$V=0.67$} & \multicolumn{4}{|c|}{$\mathrm{V}=0.51 \quad \mathrm{R}$} & \multicolumn{4}{|c|}{$\mathrm{V}=0.05 \mathrm{R}=0.05 \mathrm{VxR}=0.09$} \\
\hline
\end{tabular}

$\mathrm{SO}=$ Sour orange, $\mathrm{VL}=$ Volkamer lemon, $\mathrm{V}=$ Variety, $\mathrm{R}=\mathrm{Rootstock}, \mathrm{SO} / \mathrm{VL}=$ Interstock 


\section{El-Sayed}

Parent navel orange gave the highest values of fruit length, fruit diameter and fruit shape followed by Spring navel orange as compared with the other orange varieties in both seasons.

The effect of combined treatments between rootstock type and scions, showed that Parent navel orange budded on volkamer lemon rootstock was superior in fruit length, and diameter compared to other combination in both seasons.

This results came in contrary with results obtained by Former-Giner et al 2003 who reported that, volkamer lemon produced the larger fruits of Navelina orange than that recorded on sour orange and other tested rootstocks. In this respect, Al-Jaleel et al 2005 revealed that, the largest fruit size were obtained from Eureka lemon trees on volkamer lemon and macrophylla, whereas the smallest fruits were found on trees on Amblycarpa and Cleopatra mandarin.

Data in Table (3) cleared that fruit weight and fruit volume were greater from fruits on volkamer lemon and sour orange rootstocks than those recorded on the interstock in both seasons. As for rind thickness, it is clear that, rind thickness was thicker in fruits from trees on volkamer lemon rootstock, whereas it was thinner in fruits from trees on sour orange and interstock in both seasons, respectively. The obtained results are in agreement with those found by Economides and Gregoriou 1993 and Gregoriou 2000 .In this respect AL-Jaleel and Zekri 2003 on Washington navel orange trees budded on volkamer lemon gave fruit with thicker peel.

Parent and Spring navel oranges gave the highest values of fruit weight, fruit volume and thicker fruit as compared with the other orange varieties in both seasons.

Table (3). Effect of rootstock and interstock on fruit weight, fruit volume and rind thickness of some orange varieties in 2013 and 2014 seasons.

\begin{tabular}{|c|c|c|c|c|c|c|c|c|c|c|c|c|}
\hline Treatments & \multicolumn{12}{|c|}{ Rootstocks and interstock } \\
\hline $\mathrm{R}$ & \multicolumn{4}{|c|}{ Fruit weight $(\mathrm{g})$} & \multicolumn{4}{|c|}{ Fruit volume $\left(\mathrm{cm}^{3}\right)$} & \multicolumn{4}{|c|}{ Rind thickness $(\mathrm{cm})$} \\
\hline V & VL & so & SO/VL & Mean & VL & so & SO/VL & mean & VL & so & $\mathrm{SO} / \mathrm{VL}$ & Mean \\
\hline \multicolumn{13}{|c|}{2013} \\
\hline Olinda valencia & 203.36 & 190.36 & 214.19 & 202.64 & 194.87 & 165.12 & 195.19 & 185.06 & 0.49 & 0.38 & 0.39 & 0.42 \\
\hline Spring navel & 238.10 & 242.60 & 244.62 & 241.77 & 218.72 & 246.67 & 221.44 & 228.94 & 0.52 & 0.48 & 0.46 & 0.49 \\
\hline Parent navel & 331.27 & 290.95 & 222.04 & 281.42 & 326.25 & 370.00 & 223.50 & 306.58 & 0.52 & 0.50 & 0.47 & 0.50 \\
\hline Fukumoto navel & 223.70 & 261.93 & 239.58 & 241.74 & 208.00 & 258.67 & 212.00 & 226.22 & 0.50 & 0.49 & 0.43 & 0.47 \\
\hline Mean & 249.11 & 246.46 & 230.11 & & 236.96 & 260.12 & 213.03 & & 0.51 & 0.46 & 0.44 & \\
\hline L.S.D. at $5 \%$ & \multicolumn{4}{|c|}{$V=16.87 \quad R=12.21 \quad V x R=24.42$} & \multicolumn{4}{|l|}{$V=22.31$} & \multicolumn{4}{|c|}{$V=0.03 R=0.03 \quad V x R=0.06$} \\
\hline \multicolumn{13}{|c|}{2014} \\
\hline Olinda valencia & 222.78 & 198.22 & 228.33 & 216.44 & 185.33 & 156.11 & 177.04 & 172.79 & 0.49 & 0.38 & 0.36 & 0.41 \\
\hline Spring navel & 260.77 & 260.22 & 244.66 & 255.22 & 257.33 & 220.00 & 225.00 & 234.11 & 0.56 & 0.38 & 0.46 & 0.47 \\
\hline Parent navel & 347.57 & 347.42 & 227.79 & 307.57 & 276.50 & 270.00 & 223.50 & 256.67 & 0.50 & 0.51 & 0.43 & 0.48 \\
\hline Fukumoto navel & 211.98 & 275.52 & 239.58 & 242.36 & 209.67 & 217.00 & 212.00 & 212.89 & 0.53 & 0.50 & 0.43 & 0.49 \\
\hline Mean & 279.83 & 270.35 & 235.09 & & 232.18 & 215.78 & 209.39 & & 0.52 & 0.44 & 0.42 & \\
\hline L.S.D. at $5 \%$ & \multicolumn{4}{|c|}{$V=40.34 R=23.11 V x R=80.06$} & \multicolumn{4}{|c|}{$V=21.59 \quad R=17.58 \quad V \times R=35.16$} & \multicolumn{4}{|c|}{$V=0.07 \quad R=0.04 \quad V x R=0.08$} \\
\hline
\end{tabular}

$\mathrm{SO}=$ Sour orange, $\mathrm{VL}=$ Volkamer lemon, $\mathrm{V}=$ Variety, $\mathrm{R}=$ Rootstock, $\mathrm{SO} / \mathrm{VL}=$ Interstock 
The effect of interaction between rootstock type and scions, data in Table (3) showed that, Parent navel orange budded on volkamer lemon and sour orange rootstocks had the highest values of fruit weight and fruit volume compared to other treatments in both seasons. These results are in agreement with those obtained by Zayan et al 2004.

The results about fruit volume and weight which were greater from fruits on volkamer lemon rootstock than those recorded on sour orange rootstock are in line with those obtained by Dawood 2001 and 2002 who reported that, heavier fruit weight was obtained from valencia and Washington navel orange trees budded on volkamer lemon rootstock as compared with trees on sour orange rootstock.

Data presented in Table (4) revealed that, segments number per fruit was affected by rootstocks in both seasons. Trees budded on volkamer lemon gave fruits with more number of segments followed by those on sour orange and interstock in both seasons. The differences were significant between interstock and the two other rootstocks in both seasons. Concerning juice $\%$ / fruit, it was more in fruits from trees budded on volkamer lemon rootstock when compared with sour orange and interstock without significant differences among rootstock types in both seasons. As regard vitamin $\mathrm{C}$, it is clear that, vitamin $\mathrm{C}$ was higher in juice fruit from trees budded on volkamer lemon and sour orange rootstocks than those recorded on interstock in the first season, but in the second one, vitamin $\mathrm{C}$ was higher in fruit juice from trees budded on volkamer lemon and interstock than those recorded on sour orange (Table 4). Similar results were obtained by Mohamed (2011) and Hikal (2014).

Table (4). Effect of rootstock and interstock on segments, juice and vitamin C of some orange varieties in 2013 and 2014 seasons.

\begin{tabular}{|c|c|c|c|c|c|c|c|c|c|c|c|c|}
\hline \multirow{3}{*}{ Treatments } & \multicolumn{12}{|c|}{ Rootstocks and interstock } \\
\hline & \multicolumn{4}{|c|}{ Segments number/fruit } & \multicolumn{4}{|c|}{ Juice \% /fruit } & \multicolumn{4}{|c|}{ Vitamin $\mathrm{C}$ mg/100 ml juice } \\
\hline & $\mathrm{VL}$ & SO & $\mathrm{SO} / \mathrm{VL}$ & mean & $\mathrm{VL}$ & SO & $\mathrm{SO} / \mathrm{VL}$ & mean & $\mathrm{VL}$ & SO & $\mathrm{SO} / \mathrm{VL}$ & Mean \\
\hline \multicolumn{13}{|c|}{2013} \\
\hline Olinda valencia & 11.67 & 10.89 & 13.45 & 12.00 & 48.67 & 44.02 & 23.53 & 38.74 & 50.65 & 31.73 & 30.90 & 37.76 \\
\hline Spring navel & 13.22 & 12.89 & 11.00 & 12.37 & 31.68 & 25.27 & 32.56 & 29.84 & 44.04 & 29.36 & 23.23 & 32.21 \\
\hline Parent navel & 15.25 & 14.50 & 11.44 & 13.73 & 19.67 & 16.57 & 31.06 & 22.43 & 39.62 & 23.72 & 40.37 & 34.57 \\
\hline Fukumoto navel & 12.89 & 12.50 & 11.78 & 12.39 & 3290 & 25.88 & 33.05 & 30.61 & 32.18 & 33.27 & 26.15 & 30.53 \\
\hline Mean & 13.26 & 12.70 & 11.92 & & 33,23 & 27.94 & 30.05 & & 29.52 & 29.52 & 21.16 & \\
\hline L.S.D. at $5 \%$ & \multicolumn{4}{|c|}{$\mathrm{V}=\mathrm{ns}$} & \multicolumn{4}{|c|}{$=3.91 \quad R=2.68$} & \multicolumn{4}{|c|}{$\mathrm{V}=3.06 \mathrm{R}=2.03 \mathrm{~V} \times \mathrm{R}=7.98$} \\
\hline \multicolumn{13}{|c|}{2014} \\
\hline Olinda valencia & 12.00 & 10.89 & 13.44 & 12.10 & 43.16 & 38.74 & 27.99 & 36.63 & 45.90 & 21.35 & 28.46 & 31.90 \\
\hline Spring navel & 13.22 & 13.61 & 11.00 & 12.60 & 28.38 & 29.86 & 29.07 & 29.10 & 40.83 & 24.88 & 21.02 & 28.91 \\
\hline Parent navel & 15.25 & 14.50 & 8.24 & 12.60 & 23.05 & 22.66 & 31.35 & 25.69 & 34.49 & 21.94 & 37.96 & 31.46 \\
\hline Fukumoto navel & 12.44 & 12.50 & 11.78 & 11.24 & 33.43 & 30.58 & 33.17 & 32.39 & 28.54 & 27.50 & 25.00 & 27.01 \\
\hline Mean & 13.22 & 12.88 & 11.12 & & 32.00 & 30.46 & 30.40 & & 37.44 & 23.92 & 28.11 & \\
\hline L.S.D. at $5 \%$ & \multicolumn{4}{|c|}{$\mathrm{V}=\mathrm{ns}$} & \multicolumn{4}{|c|}{$\mathrm{V}=7.19 \quad \mathrm{R}=3.68 \mathrm{~V} \times \mathrm{R}=7.36$} & \multicolumn{4}{|c|}{$V=3.66 \quad R=2.88 \quad V \times R=5.76$} \\
\hline
\end{tabular}

$\mathrm{SO}=$ Sour orange, $\mathrm{VL}=$ Volkamer lemon, $\mathrm{V}=$ Variety, $\mathrm{R}=$ Rootstock, $\mathrm{SO} / \mathrm{VL}=$ Interstock 


\section{El-Sayed}

Segments number per fruit of Olinda valencia, Spring navel, Parent navel and Fukumoto navel oranges did not show any significant differences among them in both seasons. Juice volume/fruit was higher in Fukumoto navel orange fruit than that on the other varieties, without significant differences in most cases. Moreover, vitamin $\mathrm{C}$ was higher in Olinda valencia orange and Parent navel orange than other varieties. The obtained results agree with those found by Fallahi et al 1991 and Al-Jaleel and Zekri 2003.

Generally, Tables 2,3, 4 showed that, orange varieties budded on interstock were equal to those budded on sour orange for good physical fruit characters in terms of length, diameter, shape, volume, juice $\%$,rind thickness and segments number. However, all these parameters seemed to be better than those found on volkamer lemon rootstock. Similar results were reported by Davies and Albrigo 1994, Dawood 2002, Al-Jaleel and Zekri 2003 and Zayan et al 2004.

\subsection{Chemical fruit quality:}

Data in Table (5) showed that, fruit juice from trees budded on interstock and sour orange rootstock gave higher values of TSS than that recorded on volkamer lemon rootstock in both seasons. The differences were significant in both seasons. On the other hand, data showed that fruits juice from trees on volkamer lemon rootstock recorded higher values of total acidity than that on interstock and sour orange rootstock, respectively and the differences were significant in both seasons. As for TSS/acid ratio, the maximum values were recorded in fruits from trees on sour orange rootstock, and the minimum was recorded on those on volkamer lemon rootstock in both seasons. TSS/acid ratio in fruits harvested from trees budded on interstock was intermediate between sour orange and volkamer lemon rootstocks (Table 5). These results agree with those obtained by Economides and Gregoriou 1993 and Ennab 2003. In this respect, Perez-Zamora 2004 reveals that, lemon on volkamer lemon and macrophylla obtained a lowest quality of SSC and acidity.

Table (5). Effect of rootstock and interstock on total soluble solids (TSS), acidity and TSS/acid ratio of some orange varieties in 2013 and 2014 seasons.

\begin{tabular}{|c|c|c|c|c|c|c|c|c|c|c|c|c|}
\hline Treatments & \multicolumn{12}{|c|}{ Rootstocks and interstock } \\
\hline $\mathrm{R}$ & \multicolumn{4}{|c|}{ TSS \% } & \multicolumn{4}{|c|}{ Acidity \% } & \multicolumn{4}{|c|}{ TSS/acid ratio } \\
\hline V & VL & SO & $\mathrm{SO} / \mathrm{VL}$ & Mean & VL & so & $\mathrm{SO} / \mathrm{VL}$ & Mean & $\mathrm{VL}$ & SO & $\mathrm{SO} / \mathrm{VL}$ & Mean \\
\hline \multicolumn{13}{|c|}{2013} \\
\hline Olinda valencia & 7.83 & 9.10 & 8.97 & 8.63 & 2.17 & 1.44 & 1.73 & 1.78 & 3.63 & 6.36 & 4.77 & 4.92 \\
\hline Spring navel & 9.87 & 10.93 & 19.83 & 13.5 & 2.23 & 1.25 & 1.53 & 7 & 4.45 & 8.80 & 7.13 & 6.79 \\
\hline Parent navel & 10.97 & 11.30 & 11.00 & 11.09 & 1.66 & 0.93 & 1.12 & 1.24 & 6.79 & 12.17 & 9.82 & 9.59 \\
\hline Fukumoto navel & 9.20 & 10.30 & 11.89 & 10.46 & 1.45 & 1.14 & 1.15 & 1.25 & 6.37 & 9.02 & 8.81 & 8.07 \\
\hline Mean & 9.47 & 10.41 & 12.92 & & 1.88 & 1.19 & 1.38 & & 5.32 & 9.09 & 7.63 & \\
\hline L.S.D. at $5 \%$ & \multicolumn{4}{|c|}{$\mathrm{V}=0.72 \quad \mathrm{R}=0.42 \mathrm{VxR}=0.83$} & \multicolumn{4}{|c|}{$\mathrm{V}=0.23 \quad \mathrm{R}=0.17 \quad \mathrm{~V} \times \mathrm{R}=0.34$} & \multicolumn{4}{|c|}{$\mathrm{V}=1.89 \quad \mathrm{R}=0.96 \quad \mathrm{~V} \times \mathrm{R}=1.25$} \\
\hline \multicolumn{13}{|c|}{2014} \\
\hline Olinda valencia & 8.07 & 9.53 & 11.00 & 8.67 & 1.70 & 1.34 & 1.49 & 1.58 & 4.22 & 7.17 & 5.80 & 5.73 \\
\hline Spring navel & 10.30 & 11.47 & 11.47 & 10.92 & 1.48 & 0.99 & 1.22 & 1.30 & 6.10 & 11.60 & 9.02 & 8.91 \\
\hline Parent navel & 11.07 & 11.60 & 10.33 & 11.38 & 1.32 & 0.91 & 0.96 & 1.12 & 7.56 & 12.74 & 11.94 & 10.75 \\
\hline Fukumoto navel & 9.43 & 10.67 & 10.30 & 10.14 & 1.61 & 1.13 & 1.15 & 1.20 & 7.23 & 9.34 & 9.15 & 8.57 \\
\hline Mean & 9.72 & 10.82 & 10.30 & & 1.61 & 1.09 & 1.21 & & 6.28 & 10.21 & 8.89 & \\
\hline L.S.D. at $5 \%$ & \multicolumn{4}{|c|}{$\mathrm{V}=0.62 \quad \mathrm{R}=0.43 \quad \mathrm{~V} x \mathrm{R}=1.47$} & \multicolumn{4}{|c|}{$\mathrm{V}=0.24 \quad \mathrm{R}=0.11 \quad \mathrm{~V} \times \mathrm{R}=0.22$} & \multicolumn{4}{|c|}{$\mathrm{V}=1.51 \quad \mathrm{R}=0.49 \mathrm{~V} \times \mathrm{R}=1.77$} \\
\hline
\end{tabular}

$\mathrm{SO}=$ Sour orange, $\mathrm{VL}=$ Volkamer lemon, $\mathrm{V}=$ Variety, $\mathrm{R}=$ Rootstock, $\mathrm{SO} / \mathrm{VL}=$ Interstock 
Generally, chemical fruit properties of orange scions on interstock showed equal trend to those on sour orange rootstock for higher TSS, low acidity and higher TSS/acid ratio than those on volkamer lemon rootstock. Similar results were reported by Davies and Albrigo 1994; they reported that C. volkameriana produced relatively poor fruit quality with less SSC characterized by higher acidity and course peel.

The obtained results in this study supported the idea of intermediate stock such as sour orange on volkamer lemon rootstock and experimentally led to improve most chemical and physical fruit properties of the scions budded on them. Therefore, using sour orange as interstock for most orange varieties on volkamer lemon is recommended to maintain high productivity with proper fruit quality, especially in the new reclaimed soils in Egypt.

\section{REFERENCES}

Al-Jaleel, A. and M. Zekri (2003). Effect of rootstocks on yield and fruit quality of "Parent Washington navel" trees. Proc. Fla. State Hort. Soc., 116: $270-275$.

Al-Jaleel, A., M. Zekri and Y. Hammam (2005). Yield, fruit quality and tree health of "Allen Eureka" lemon on seven rootstocks in Saudi Arabia, Scientia Hort. 105: 457 - 465.

Association of official Agriculture chemists (1990). Official and tentative methods of analysis, (the AOAC 11 Ced. Washington, D. C., USA.).

Davies, F. S. and L. G. Albrigo (1994). Rootstocks in: Atherton, J., Rees. A. (Eds). Citrus $C A B$ International. Walling Ford. UK. Pp. $83-107$.

Dawood, S. A. (2001). Growth, yield, fruit quality and leaf mineral content of Valencia orange trees on Sour orange and Volkamer lemon grown on slightly alkaline clay soil. J. Agric. Res. Tanta Univ., 27 (4): 726 - 736.

Dawood, S. A. (2002). Evaluation of Washington navel orange on Sour orange and Volkamer lemon grown on slightly alkaline clay soil conditions. J. Agric. Res. Tanta Univ., 28(1): 157- 167.

Economides, C. V. and C. Gregoriou (1993). Growth, yield and fruit quality of nucellar frost "March" grapefruit on fifteen rootstocks in Cyprus. J. Amer. Soc. Hort. Sci., 118 (63): 326 - 329.

Ennab, H. A. (2003). Evaluation study on Washington navel orange cultivar budded on five rootstocks. pH. D. thesis, Fac. Agric. Kafr El-Sheikh, Tanta University.

Fallahi, E., J. N. Moon, Jr and D. R. Rodney (1989). Yield and quality of "Red-blush" grapefruit on twelve rootstocks. J. Amer. Soc. Hort. Sci., 114 : 187 - 190.

Fallahi, E., Z. Mousavi and D. R. Rodney (1991). Performance of "Orlando" trees on ten rootstocks in Arizona. J. Amer. Soc. Hort. Sci., 116: $2-5$.

Former-Giner, M. A., A. Alcaide, E. Primo Millo and J. B. Foner (2003). Performance of "Navelina" orange on 14 rootstocks in northern Valencia (Spain). Scientia Hort., 98: 223 - 232.

Gregoriou, A. (2000). Performance of "Nova" mandarin on eleven rootstocks in Cyprus. Scientia Hort., 84 : $115-126$.

Gregoriou, A. (2002). Evaluation of rootstocks for "Clementine" mandarin in Cyprus. Scientia Hort., 93 : $29-38$.

Hikal, A. R. F. (2014). Effect of different rootstocks on vegetative growth, fruiting, fruit quality and fruit storage on trees of Washington navel orange. J. Plant Production, Mansoura Univ., 5(2):347 355.

Jacobs, M. B. (1951). The chemical analysis of foods and food products: $724-732$. D. Van. Nostrand., Inc. Now York, London.

Mohamed, M.A. (2011). Effect of some citrus rootstocks on vegetative growth and leaves mineral content of Balady lime transplants. M.Sc. Thesis, Fac. of Agric. Ain-Shams Univ., Cairo, Egypt.

Perez - Zamora, O. (2004). Leaf nutrient concentration, Yield, production efficiency, juice quality and nutrimental indexes on Valencia orange grafted on citrus rootstocks. ARTICULO en Agro ciencia $38: 141-154$.

Snedecor, G.W. and W.G. Cochran (1990). Statistical methods. 7th Ed. lowa State Univ. Press. Ames., lowa, USA.

Zayan, M. A., S. M. Zeerban, H. M. Ayaad, S. A. Dawood and H. A. Ennab (2004). Evaluation study on Washington navel orange cultivar budded on five rootstocks. 2- Flowering, yield and fruit quality. J. Agric. Res. Tanta Univ., 30 (2): $421-436$. 


\title{
تاثير الاصل و الاصل الوسطى على النمو و المحصول وصفات الجودة لثمار بعض اصناف البرتقال
}

ب- التأثيرعلى الخصائص الطبيعيه و الكيميائيه للثمار لبعار

\author{
سمية أحمد السيد \\ قسم الموالح - معهد بحوث البساتين - مركز البحوث الزراعية بالجيزة - مصر
}

الملخص العربي

اجرى هذا البحث خلال موسمى 2013- 2014 بمزرعه خاصه بمنطقه البستان بمحافظه البحيره بهدف دراسه ثأثير

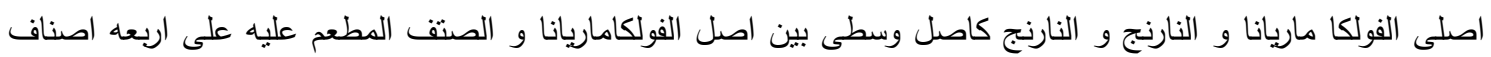

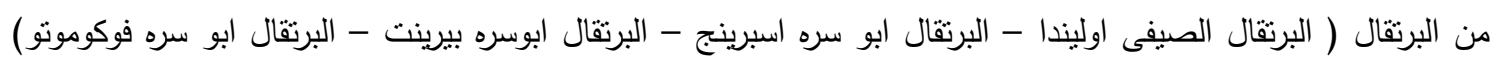

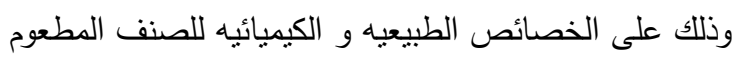

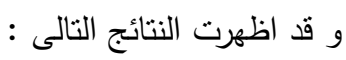

1- أظهرت النتائج عدم وجود فروق معنويه بين الأصول الثلاثه بالنسبه لطول و قطر وشكل الثمره فى معظم الحالات فى كلا الموسمين فيما عدا الاصناف على اصل الفولكاماريانا الذى اظهر اختلاف معنوى فى شكل الثمره فى الموسمين ،

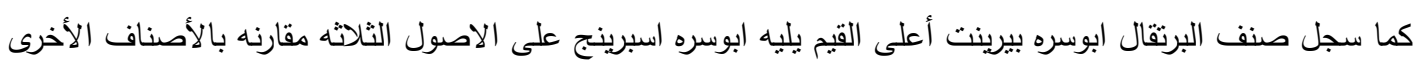

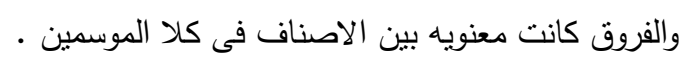
2- سجلت أعلى القيم لوزن و حجم الثمره و سمك القشره على ثمار الاصناف المطعومه على أصلى الفيه الفولكاماريا مقارنه

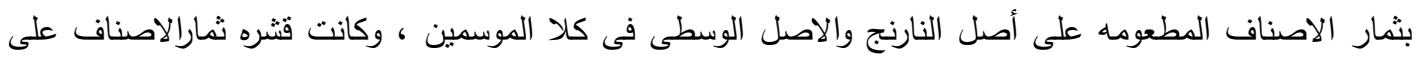

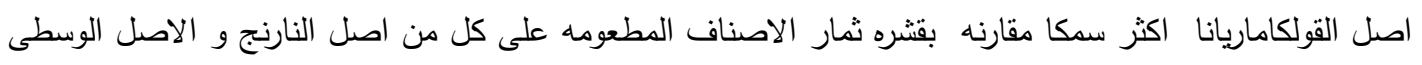
التى كانت اقل سمكا. 3- - أظهرت النتائج أن أصناف البرتقال المطعومه على الاصل الوسطى كانت مماثله للاصناف المطعومه على أصل

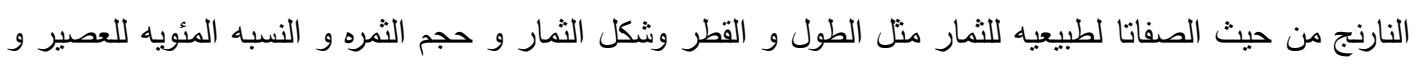

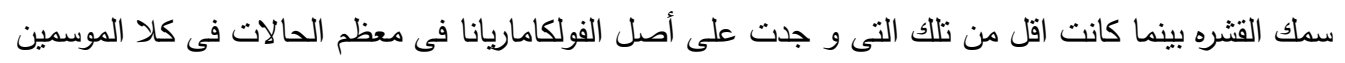

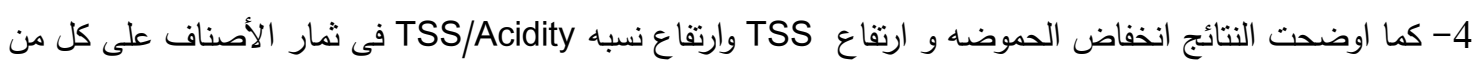

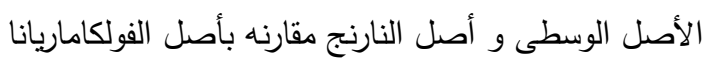

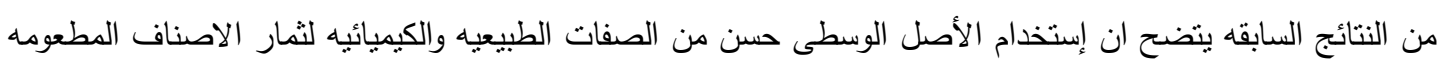

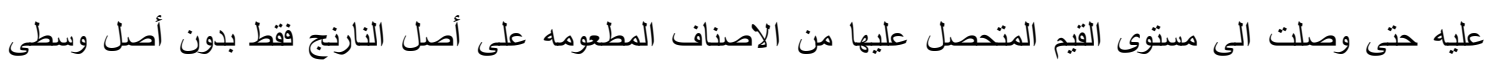

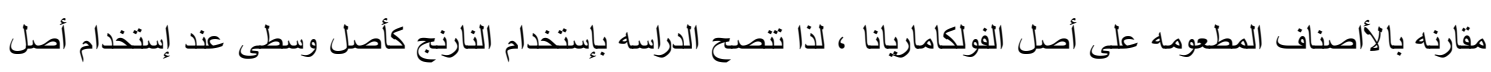
الفولكا ماريانا كأصل للتطعيم عليه وذللك لتفادى بعض العيوب المتعلقه بالصفات الطبيعيه و الكيميائيه للثمار . 
Effect of rootstock and interstock on growth, yield and fruiy quality ........... 